\title{
ANTIOXIDANT PROPERTIES OF COCOA (THEOBROMA COCOA L.) SHELL POWDER IN FERMENTATION AND IMMERSION TREATMENTS
}

\author{
Elazmanawati Lembong ${ }^{1}$, Mohamad Djali' ${ }^{1}$, Gemilang Lara Utama ${ }^{1,2}$ \\ ${ }^{1}$ Department Food Technology Industry, Faculty Technology Industry of Agriculture, Universitas Padjadjaran, \\ Jl. Raya Bandung-Sumedang KM 21, Jatinangor, Sumedang, Indonesia \\ ${ }^{2}$ Center for Environment and Sustainability Science, Universitas Padjadjaran, Jl. Sekeloa Selatan I No. 1, Bandung, \\ Indonesia
}

Link to this article: https://doi.org/10.11118/actaun.2021.048

Received: 19. 4. 2021, Accepted: 14. 7. 2021

To cite this article: LEMBONG ELAZMANAWATI, DJALI MOHAMAD, UTAMA GEMILANG LARA. 2021. Antioxidant Properties of Cocoa (Theobroma cocoa L.) Shell Powder in Fermentation and Immersion Treatments. Acta Universitatis Agriculturae et Silviculturae Mendelianae Brunensis, 69(4): 533-541.

\begin{abstract}
Cocoa shell is a waste of the cocoa processing industry, containing vitamin D, protein, fat, carbohydrates, and fiber as well as antioxidant compounds such as polyphenols. Fermentation and immersion processes are needed in post-harvest cocoa to create the distinctive taste and flavor of chocolate, as well as to produce cocoa bean shell powder, which is also good quality as a waste utilization. This study aims to determine the effect of fermentation and immersion processes on the antioxidant activity and characteristics of the cocoa bean shell powder (CBS). The research method used a completely randomized design (CRD) method with four treatments e.g. NFNI (Non Fermentation Non Immersion), NFI (Non Fermentation Immersion), FNI (Fermentation Non Immersion) and FI (Fermentation Immersion) with three replications. The results of the color parameters show that CBS has a yellow-red color with significantly different $\mathrm{L}^{*}$ values following the order FNI $>$ NFNI $>$ FI $>$ NFI and the $a^{*}$ and $b^{*}$ values following the order $\mathrm{FNI}<\mathrm{FI}<\mathrm{NFNI}<\mathrm{NFI}$. NFNI has the highest antioxidant activity with IC50 values of $12.93 \mathrm{ppm}$ and total phenolic $4.33 \mathrm{~g} / 100 \mathrm{~g}$ followed by NFI, FNI, and FI. The best treatment for texture, aroma and color parameters was FI with an average value above 7 , and it also had overall appearance characteristics that were not significantly different from commercial cocoa powder.
\end{abstract}

Keywords: cocoa shell powder, antioxidant, organoleptic

\section{INTRODUCTION}

Cocoa (Theobroma cocoa L.) is one of the plantation commodities that has a substantial contribution to the Indonesian economy from the non-oil and gas sector by creating employment, increasing income, and increasing the country's foreign exchange reserves (Indriati et al., 2020). Based on data from (Direktorat Jenderal Perkebunan, 2016), the total Indonesian cocoa production is 850 thousand tons. This value makes Indonesia the $3^{\text {rd }}$ largest cocoa producer country in the world after Ivory Coast and Ghana. Cocoa production in Indonesia tends to increase every year in line with the development of government programs.

Cocoa production, which is growing year after year, has the potential to increase more waste. The annual production of cocoa bean waste was projected to be 60,000 tons in 2014 (Utami et al., 2017). Cocoa bean shell waste, which is plentiful, is often not properly used and can potentially be a pollutant if left unchecked, much like industrial waste, animal feed, and fertilizer (Barišić et al., 2020). According to (Kayaputri et al., 2014), the cocoa bean shell contains functional components 
such as theobromine, caffeine, and polyphenols that are similar to those found in cocoa beans. These compounds are phytochemical components of secondary metabolites from plants.

Phenolic compounds contained in cocoa bean shell extract include alkaloids, tannins, triterpenoids, saponins, and flavonoids. These are active compounds with the ability to serve as natural antioxidants. The presence of phenolic compounds can help prolong the shelf life of chocolate products by preventing the oxidation of cocoa fat, which can contribute to rancidity (Indah et al., 2015; Shahidi and Ambigaipalan, 2015).

Cocoa bean shell powder has similarities with cocoa powder, especially in terms of color and aroma. Based on these similarities, the utilization of shell waste can be increased to powder, but the cocoa bean shell powder is still high in cellulose content, which is in the ranges of $17.27 \%$ to $35 \%$ (Redgwell et al., 2003; Wijaya et al., 2018). So that the cocoa bean shell powder can not be consumed directly, but can be used as a mixture of ingredients in the manufacture of sweet toppings, cake ingredients, and drinks. Aside from being able to be used as food additives, the cocoa bean shell powder can also be utilized as a polyphenol compound as a natural antioxidant, natural coloring, and food preservative through the extraction process (Handojo et al., 2019; Rojo-Poveda et al., 2020).

Cocoa can be classified based on the process e. g. fermented and non-fermented cocoa beans. Non-fermented beans are the most common in Indonesia (Apriyanto et al., 2016; Gu et al., 2013). Slaty beans, gray color, high seed acidity, low taste, very bitter and coarse, solid texture, non-uniform seed size, high impurities, and many infected by insects, fungi, and mycotoxins are all characteristics of fermented cocoa beans product (Sudibyo, 2017; Wahyudi et al., 2013).

These undesirable characteristics can be overcome by applying the right cocoa fermentation process so that the quality of cocoa beans can be produced. Fermentation of cocoa beans will make the brown color of the cocoa seed, reducing the bitter, sour, sweet, and floral aroma, increasing the aroma of chocolate and nuts (nutty) and hardening the seed coat into shells (Afoakwa et al., 2008).

The acidity of fermented dry cocoa beans is still very high (Wahyuni et al., 2018). To solve these issues, a simple and effective process, such as immersion, is needed. Soaking and washing seeds can also help to avoid the fermentation process, speed up the drying process, improve the appearance of the seeds, minimize the amount of acetic acid in the seeds, and increase the percentage of round seeds (Hatmi and Rustijarno, 2012).

According to (Towaha et al., 2012), changes in the content of phenolic compounds in cocoa were highly influenced by cocoa processing, especially fermentation. Natural antioxidants and phenolic compounds found in cocoa bean shells are a factor that has the potential to be used further. Antioxidant compounds can be present in the shells of cocoa beans, but no information on the impact of fermentation and immersion on antioxidant compounds in cocoa bean shell powder. So that, it is necessary to investigate the antioxidant function and characteristics of the fermented and immersed cocoa bean powder. Based on the description above the impact of fermentation and immersion processes on the antioxidant activity and characteristics of cocoa bean shell powder need to be investigated.

\section{MATERIALS AND METHODS}

\section{Cocoa Bean Shell Treatments}

Bulk cocoa fruits obtained from the Sari Mulyo Farmers Group Gambiran Patuk Gunungkidul, Yogyakarta. Commercial cocoa powder is also used as a comparison obtained from the market ("Windmolen"). The research method used a completely randomized design (CRD) method with four treatments and three replications as follows: NFNI = Non Fermentation Non Immersion, NFI = Non Fermentation, Immersion (t: 25 minutes), FNI $=$ Fermentation (t: 5 days) Non Immersion and $\mathrm{FI}=$ Fermentation (t: 5 days), Immersion (t: 25 minutes).

\section{Cocoa Bean Shell Powder Color Testing}

Cocoa bean shell powder tested by using CIE Lab method (Romaniello et al., 2015). The data obtained are in the form of $\mathrm{L}^{*}, \mathrm{a}^{*}$, and $\mathrm{b}^{*}$ values. The value $L^{*}$ indicates the light, $a^{*}$ shows the $\mathrm{red} /$ green coordinates, and b* shows the yellow/blue coordinates. A higher $\mathrm{L}^{*}$ value indicates the lighter color of a sample. Conversely, a lower $\mathrm{L}^{*}$ value indicates the darker the color of the sample. The higher the $a^{*}$ value indicates that the sample color is closer to red, the lower the $\mathrm{a}^{*}$ value indicates the color of the sample is closer to green. The higher the $\mathrm{b}^{*}$ value indicates the color of the sample, the closer to the yellow color, and the lower the $\mathrm{b}^{*}$ value, the closer the color of the sample to the blue color. The HUE value is calculated by converting the $\mathrm{L}^{*} \mathrm{a}^{*} \mathrm{~b}^{*}$ value to determine the chromaticity color range area using the following formula and matched with chromacity color range area (Pathare et al., 2013).

HUE $=\tan -1(b / a)$

\section{Cocoa Bean Shell Powder Manufacturing Stage}

The process of making cocoa bean shell powder started with preparing dried cocoa beans with four treatments. The same-sized cocoa beans were then roasted for 40 minutes at $140{ }^{\circ} \mathrm{C}$. To avoid overroasted, cocoa beans were cooled with a blower. A deshaller machine was used to separate the cocoa 
bean shell from the seeds. The cocoa bean shell was milled for 25 seconds using a grinder. Sift the cocoa bean shell using an 80 mesh Tyler sieve to homogenize its size. The samples were then packed in the airtight aluminum package and stored in a desiccator to minimize water absorption before testing.

\section{Production Phase of Cocoa Bean Shell Powder Extract}

The cocoa bean shell powder was extracted to obtain the active compound for antioxidant and total phenolic activity. Cocoa bean shell powder macerated using $70 \%$ ethanol solvent with a ratio of powder and solvent 1:5 (w/v) for 24 hours at room temperature. Separate the filtrate (extract of 70\% ethanol-soluble cocoa beans) and pulp (cocoa bean shell powder) using a vacuum filter, then store in an airtight container. The filtrate was concentrated, using a rotary evaporator at $45^{\circ} \mathrm{C}$ to eliminate the solvent (ethanol), yielding a concentrated extract of cocoa shells which soluble in ethanol 70\%.

\section{The Antioxidant Activity}

The antioxidant activity of cocoa bean shell powder extract was measured using the DPPH (2,2-diphenyl-1-picrylhydrazyl) method with a UV-Vis spectrophotometer. DPPH $160 \mathrm{ppm}$ was prepared by dissolving DPPH $16 \mathrm{mg}$ in y $100 \mathrm{ml}$ of methanol and homogenized using a vortex. The test sample in the form of CBS extract was prepared as much as $2 \mathrm{ml}$ and added $0.5 \mathrm{ml}$ of DPPH. Then the solution was incubated for 30 minutes at $27^{\circ} \mathrm{C}$ until a color change occurred. The solution is ready to measure its absorbance using a UV-Vis spectrophotometer.

The addition of DPPH solution to the sample was marked by changing from purple to yellow, which meant the process of capturing free radicals. The amount of antioxidant activity was indicated by the IC50 value (50\% inhibition concentration), which was the concentration of the sample solution needed to inhibit 50\% of DPPH free radicals. The $50 \%$ inhibition was obtained from the curve between the percent inhibition of the sample concentration of the equation.

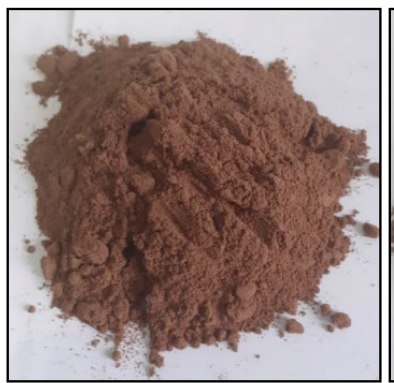

NFNI

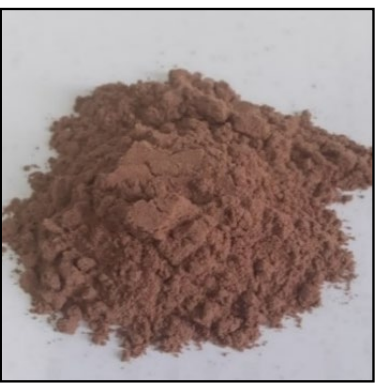

NFI

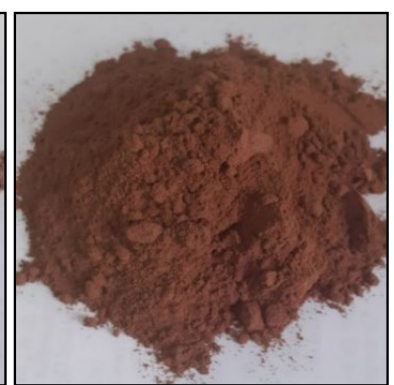

FNI

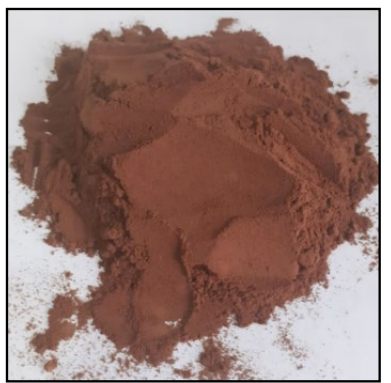

FI

1: Visual appearance of cocoa bean shell powder 
I: Value of L*, $a^{*}, b^{*}$, and HUE for Cocoa Bean Shell Powder

\begin{tabular}{lccccc}
\multicolumn{1}{c}{ Treatment } & $\mathrm{L}^{*}$ & $\mathrm{a}^{*}$ & $\mathrm{~b}^{*}$ & Hue & Color range \\
\hline NFNI & $46.08 \pm 0.49 \mathrm{a}$ & $10.77 \pm 0.60 \mathrm{a}$ & $16.99 \pm 0.66 \mathrm{a}$ & $57.64 \pm 0.44 \mathrm{a}$ & \\
NFI & $42.50 \pm 0.91 \mathrm{~b}$ & $11.64 \pm 0.48 \mathrm{a}$ & $18.97 \pm 0.80 \mathrm{a}$ & $58.44 \pm 0.13 \mathrm{~b}$ & \\
FNI & $55.33 \pm 0.62 \mathrm{~b}$ & $8.51 \pm 0.14 \mathrm{~b}$ & $16.04 \pm 0.11 \mathrm{a}$ & $62.05 \pm 0.36 \mathrm{c}$ & Yellow Red (YR) \\
FI & $45.96 \pm 0.28 \mathrm{c}$ & $8.66 \pm 0.09 \mathrm{c}$ & $16.28 \pm 0.36 \mathrm{~b}$ & $61.98 \pm 0.37 \mathrm{c}$ & \\
\hline
\end{tabular}

Note: The average treatment which is marked with the same letter states that it is not significantly different at the $5 \%$ test level based on the Duncan test

the color of FNI is the lightest and similar to natural cocoa powder (Valverde García et al., 2020).

Cocoa bean shell powder with fermentetion treatment has $\mathrm{L}^{*}$ values of 45.96 (FI) and 55.33 (FNI). This value was significantly different and higher than the non-fermentation treatment of 42.50 (NFI) and 46.08 (NFNI). So that fermentation treatment has a brighter color than without fermentation. Cocoa bean shell powder with immersion treatment has L* values of 42.50 (NFI) and 45.96 (FI). This value was significantly different and lower than the non-immersion treatment of 46.08 (NFNI) and 55.33 (FNI). So that the soaking treatment has a darker color than without soaking.

According to (Septianti et al., 2020; Suazo et al., 2014), fermented cocoa powder has a dark brown (blackish) color than non-fermented cocoa powder due to the fermentation process. The color of the cocoa beans started to change from gray to purple on the second day of fermentation; on the fourth day of fermentation, the beans are still mostly brownish purple, and on the sixth day of fermentation, the beans are entirely fermented, with dark brown color covering approximately $80 \%$ of the outer skin. Fermentation time and drying time are the factors that played a role in the decomposition of polyphenol compounds which resulting in the brown color of the cocoa beans. In the drying process, tannins are responsible for the formation of various colors of cocoa powder (Septianti et al., 2020).

The $a^{*}$ values of cocoa beans shell powder are in the following order: FNI $<$ FI $<$ NFNI $<$ NFI. The $a^{*}$ value of cocoa bean shell powder was significantly affected by the treatment which ranged from 8.51 to 11.65 . The $a^{*}$ value of the samples given the fermentation treatment FI is 8.66, which is significantly different and lower than the NFI of 11.64; and the FNI of 8.51 which is significantly different and the value was lower than the NFNI of 10.77. This due to the fermentation process which reducing anthocyanins, a red dye color, by the degradation into other polyphenol monomers (Suazo et al., 2014).

The $b^{*}$ value of cocoa bean shell powder was significantly affected by each treatment. The $\mathrm{b}^{*}$ values of powdered cocoa bean shells powder ranged from 18.97 to 16.04. The fermented treated cocoa bean shell powder tends to have a lower b* value compared to non-fermented treatments. This means that fermented cocoa beans have a more blueish color, while the non-fermented treatment is more yellowish.

The hue value of cocoa bean shell powder was significantly affected by the NFNI, NFI, FNI, and FI treatments range from 57.64 to 62.05 . This results in a yellow-red color in all cocoa bean shell powder treatments. The brown color in cocoa is due to the polyphenolic material (Septianti et al., 2020). The hue value is the identity of a color, obtained by the formula tan-1 (b/a) (Peña-Saldarriaga et al., 2020). The hue value of the NFNI treatment was 57.64 which tended to have the lowest hue value than the other treatments, indicating that the NFNI colored yellow-red tended to be stronger to red than yellow.

\section{Antioxidant Activity and Total Phenolic Extract of Cocoa Bean Shell Powder}

Antioxidants in food play an important role as a substance that can inhibit the effects of free radicals by preventing oxidation reactions from free radicals (Lobo et al., 2010). The IC50 value of an extract can be used to determine the antioxidant activity, which indicated the ability of antioxidants to reduce 50\% concentration of DPPH free radicals. The higher the IC50 value, the lower the antioxidant activity, whereas the lower the IC50 value, the higher the antioxidant activity (Rohmah et al., 2020). The results of the analysis of the IC50 value and total phenolic of cocoa bean shell powder extract can be seen in Fig. 2.

IC50 values of cocoa bean shell powder extracts were significantly different among the treatments. The value of IC50 of the NFNI treatment resulting in $12.93 \mathrm{ppm}$ that is significantly different with other treatments. Meanwhile NFI treatment with $16.69 \mathrm{ppm}$ IC50 value was not significant with the FNI treatment with FNI treatment (18.11 ppm) and significantly different with the treatment of NFNI $(12.93 \mathrm{ppm})$ and FI (21.33 ppm). The statistical difference also found in total phenolic results which shows that NFNI treatment $(4.33 \mathrm{~g} / 100 \mathrm{~g})$ is non significant with the NFI treatment $(4.25 \mathrm{~g} / 100 \mathrm{~g})$, while significantly different with FNI (3.41 g/100 g) and FI $(2.48 \mathrm{~g} / 100 \mathrm{~g})$. The FNI treatment is non significant with the all of treatment including FNI and FI. 


\section{Antioxidant activity and total phenolic}

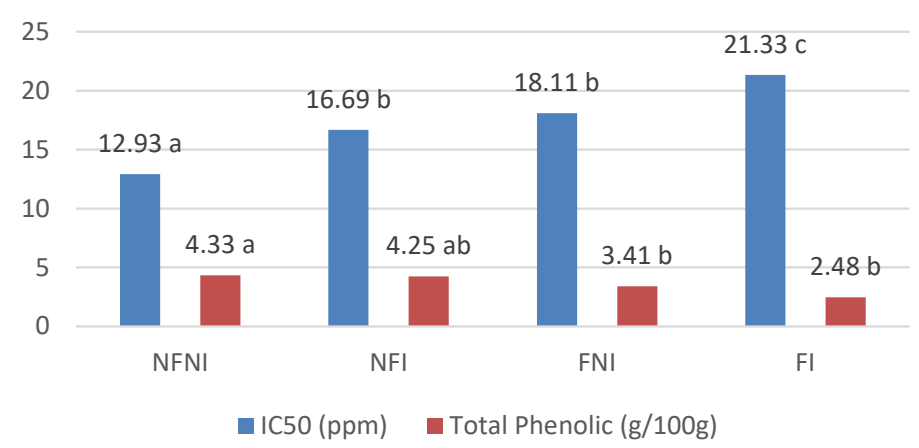

2: Antioxidant activity and total phenolic extract of cocoa bean shell powder Note: The average treatment marked with the same letter states no significant difference at the $5 \%$ test level based on the Duncan test

IC50 values of cocoa bean shell powder extract ranged from $21.33 \mathrm{ppm}$ to $12.93 \mathrm{ppm}$. The antioxidant activity of cocoa bean shell powder is classified as very strong because it has an IC50 value of $\leq 50$ ppm (Rojo-Poveda et al., 2020; Utama et al., 2020). These results indicate a higher antioxidant activity than the results of the study of (Utami et al., 2017), which stated that the antioxidant activity of cocoa bean shells was 107.93 ppm which was classified as weak (IC50 > 50-200 ppm) (Rojo-Poveda et al., 2020).

The extracts of CBS powder have IC50 values of $21.33 \mathrm{ppm}$ (FI), $18.11 \mathrm{ppm}$ (FNI), $16.69 \mathrm{ppm}$ (NFI), and $12.93 \mathrm{ppm}$ (NFNI). The non-fermentation and non-immersion (NFNI) treatment has the lowest IC50 as compared to the other treatments, indicating that NFNI has the highest antioxidant activity. While the fermentation treatment FI anf FNI have a higher IC50 values which are significantly different to NFNI, so that the antioxidant activity was lower with FI being the loweset. The total phenolic content of CBS ranged from 2.48 to $4.33 \mathrm{~g} / 100 \mathrm{~g}$ with NFNI being the highest with a value of $4.33 \mathrm{~g} / 100 \mathrm{~g}$ (4.33\%), and other treatments NFI 4.25, FNI $3.41 \mathrm{~g} / 100 \mathrm{~g}$ and FI $2.48 \mathrm{~g} / 100 \mathrm{~g}$. Based on these result, there is a correlation between antioxidant activity and total phenolic content. The higher the total phenolic, the higher the antioxidant activity (the lower the IC50 value). This result in line with Wiboonsirikul et al. (2007), which stated total phenolic levels have a linear correlation with antioxidant activity.

An increase of IC50 values in fermentation treatment of $\pm 8.4 \mathrm{ppm}$ means a decrease in antioxidant activity by $64.96 \%$ as compared to the non-fermentation treatment. These results in line with (Aikpokpodion and Dongo, 2010), which states that cocoa fermentation 5-6 days causes a decrease in antioxidant activity by $63 \%$ compared to without fermentation. As the fermentation process lengthens, the DPPH radical inhibitory activity decreases, implying that the decline in antioxidant activity is due to a decrease in polyphenols (da Silva Medeiros et al., 2015). The reduction is mainly caused by the fermentation, drying, and roasting processes. The content of phenolic compounds is significantly reduced during the fermentation process due to oxidation caused by enzymatic reactions, which is aided by oxygen, diffusion of polyphenols from cotyledons, polymerization processes, condensation processes, and protein binding processes (Adebo and Gabriela Medina-Meza, 2020).

Non-fermentation cocoa bean shell powder extracts (NFNI and NFI) had higher total phenolic levels compared to fermentation treatments (FNI and FI), which fell by $\pm 42.725 \%$ from $4.33 \mathrm{~g} / 100 \mathrm{~g}$ to $2.480 \mathrm{~g} / 100 \mathrm{~g}$. This result is in line with (Misnawi and Selamat, 2003), that fermentation of fresh cocoa beans for 5 days could reduce polyphenol compounds $\pm 53.4 \%$ from the initial polyphenols by $135.1 \mathrm{~g} / \mathrm{kg}$ to $72.1 \mathrm{~g} / \mathrm{kg}$. The same thing was stated by (Serra Bonvehí and Ventura Coll, 1997) that the content of phenol compounds due to fermentation decreased by $\pm 63 \%$ from $150 \mathrm{mg} / \mathrm{g}$ to $55 \mathrm{mg} / \mathrm{g}$. Furthermore, this finding is also in line with (Tomas-Barberán et al., 2007) who stated that phenol compounds in fermented dried cocoa beans were reduced from $7.8 \mathrm{~g} / 100 \mathrm{~g}$ to $4 \mathrm{~g} / 100 \mathrm{~g}$ dry weight or nearly $50 \%$. The decline in polyphenol compounds reached 10-50\% (Camu et al., 2008).

The decrease in the content of phenolic compounds during fermentation was due to the oxidation of phenol compounds by the enzyme polyphenol oxidase (PPO), the diffusion of phenols from cotyledons to the skin layer, and the polymerization of phenolic compounds especially epicatechin and proanthocyanidin to form tannin compounds and the formation of complexes with protein and polysaccharides (Afoakwa et al., 2012; De Brito et al., 2001; Misnawi and Selamat, 2003). The occurrence of phenol polymerization reactions and the formation of complexes with other compounds, adding to the solubility of phenols lost by the pulp fluid. This also causes the total phenolic levels of the immersion treatment to be lower than non-immersion (Afoakwa et al., 2013; Di Mattia et al., 2013). 
The longer the immersion, the lower the total phenolic content. This can be caused by the browning reaction catalyzed by the polyphenol oxidase (PPO). This reaction occurs when plant cells are broken down by cuts or destruction, wherein the phenolic indigenous compound is oxidized in the presence of oxygen molecules to produce brown pigments (Taranto et al., 2017).

\section{Cocoa Beans Powder Scoring Test}

The results of the texture, aroma and color scoring test can be seen in Fig. 3. Fig. 3 shows that each treatment affects significantly the texture of cocoa bean shell powder. The texture of the cocoa bean shell powder earned the highest degree of panelist scoring in treatment FI. This is because the cocoa bean shell has a smooth texture, the pulp layer has thinned, and the pulp layer's color has shifted to transparent (Hayati et al., 2012). The panelists' scores on the texture of cocoa bean shell powder ranged from 5.17 to 7.70 in the tests.

The aroma scores of cocoa bean shell powder are significantly different affected by each treatment, ranged from 4.23 to 7.97. Treatment NFNI had an average of 4.23, treatment NFI had an average of 5.70, treatment $C$ had an average of 6.77 , and treatment FI had an average of 7.97. The highest aroma parameters of cocoa bean shell powder were graded in the following order FI, FNI, NFI, and NFNI. This implies that as compared to other treatments, cocoa bean shell powder FI had a greater cocoa bean aroma. Non-fermentation non-immersion (NFNI) obtained the lowest score, which is in line with (Ndukwu and Udofia, 2016; Septianti et al., 2020), which reports that unfermented cocoa beans lack the distinctive scent of chocolate and have an excessive amount of astringency and bitterness. This is attributable to the distinctive scent of chocolate that occurs during fermentation; without fermentation, the distinctive cocoa scent doesn't exist (Hayati et al., 2012; Ndukwu and Udofia, 2016). The immersion treatment resulting in higher scores of aroma compared to non-immersion. The immersion treatment allowed dirt or odors such as soil odor, mold, or other odor contamination on the cocoa bean shell to be lost or washed so that these conditions could affect the aroma attribute of cocoa bean shell powder.

The color of cocoa bean shell powder is significantly affected by each treatments. Treatment NFNI had an average of 4.23, treatment NFI had an average of 5.57, treatment FNI had an average of 6.63, and treatment FI had an average of 7.57. Fermentation time and drying time are two factors that affect the formation of the brown color (Ndukwu and Udofia, 2016; Septianti et al., 2020). Based on the reaction, the brown color can be caused by a non-enzymatic and enzymatic reaction. The nonenzymatic reactions like the hydrolysis of anthocyanins into anthocyanidins, and the reaction between reducing sugar and the amino groups of proteins (Maillard reaction) resulting in a brown color. The enzymatic reaction occurs during fermentation and drying which involves the formation of quinones from phenolic compounds and the later formation of brown to black polymers under the action of the polyphenol oxidase (Suazo et al., 2014; Taranto et al., 2017; Valverde García et al., 2020).

\section{CBS powder Scoring Result}

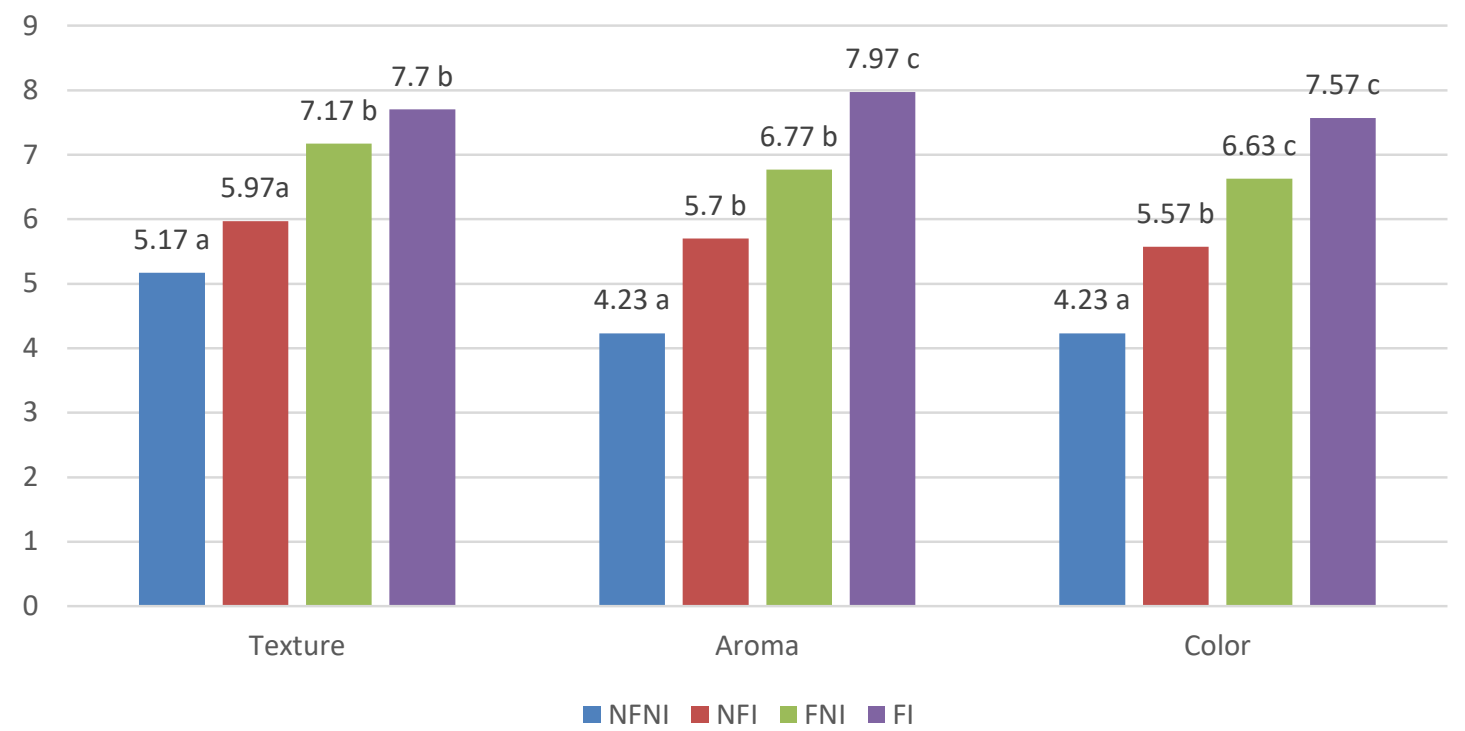

3: Scoring results texture, aroma and color of cocoa bean shell powder

Note: The average treatment marked with the same letter states no significant difference at the 5\% test level based on the Duncan test 
II: The result of triangle test cocoa shell powder and commercial cocoa powder

\begin{tabular}{|c|c|c|c|c|c|c|c|c|c|c|c|c|c|c|}
\hline \multicolumn{12}{|c|}{ Parameter } & \multirow{3}{*}{\multicolumn{3}{|c|}{$\begin{array}{l}\text { The smallest } \\
\text { amount for the level } \\
\text { significant difference }\end{array}$}} \\
\hline \multicolumn{3}{|c|}{ Color } & \multicolumn{2}{|r|}{ Aroma } & & \multicolumn{3}{|c|}{ Texture } & \multicolumn{3}{|c|}{ Overall Appearance } & & & \\
\hline \multicolumn{12}{|c|}{ Code } & & & \\
\hline 166 & 222 & 697 & 166 & 222 & 697 & 166 & 222 & 697 & 166 & 222 & 697 & $5 \%$ & $1 \%$ & $0.1 \%$ \\
\hline 2 & 9 & 4 & 1 & 11 & 3 & 2 & 11 & 2 & 3 & 8 & 4 & 9 & 10 & 12 \\
\hline
\end{tabular}

Note: Code explanation 166 and 697 are Cocoa Bean Shell Powder Best Treatment (FI) and code 222 is Cocoa powder "Windmolen"

The highest order of scoring data for cocoa bean shell powder color was FI, FNI, NFI, and NFNI. The highest panelist scoring rate for color was in treatment FI, while the lowest value was in treatment NFNI. This finding is in agreement with (Hayati et al., 2012). who found that the panelist preference level for the color produced is highest in cocoa treated with fermentation, whereas the lowest value is obtained in cocoa treated without fermentation, which produces a whitish brown color due to the presence of a pulp layer. Unfermented cocoa bean shells will also form dark patches as sugar compounds dry (Hayati et al., 2012).

\section{Triangle Test of FI Cocoa Shell Powder Compared With Commercial Cocoa Powder}

The result of triangle test can be seen in the following Tab. II. Tab. II shows that 11 out of 15 panelists could tell the difference between treatment FI cocoa bean shell powder and commercial cocoa powder in terms of aroma and texture. Merely 9 out of 15 panelists can tell the difference in the color between cocoa bean shell powder and cocoa powder. According to the overall appearance parameters, 8 panelists responded correctly about different samples out of a total of 15 panelists used, and 7 panelists were unable to distinguish the overall appearance of cocoa bean shell powder from cocoa powder. The overall appearance was assessed thoroughly by panelists.

The smallest amount for the level significant difference states that out of the 15 panelists to state that there were real differences from the three samples tested, a minimum of 9 appropriate responses for the 5\% level, 10 appropriate responses for the 1\% level, and 12 appropriate responses for the $0.1 \%$ level. If the correct number of responses was less than 9, the conclusion is that no difference can be detected between the three samples. Based on the observations in Tab. II, the aroma and texture parameters contained 11 appropriate responses recognizing different samples. So for the sample of cocoa powder and cocoa bean shell powder with aroma and texture parameters had significantly different quality characteristics at the level of $1 \%$. Judging from the color parameters, it is known that there were 9 appropriate responses. So for the sample of cocoa powder and cocoa bean shell powder with color parameters had significantly different quality characteristics at the level of 5\%. Judging from the overall appearance parameters, there were 8 appropriate responses. So for the sample of cocoa powder and cocoa bean shell powder with overall appearance parameters had quality characteristics that were not significantly different.

\section{CONCLUSION}

Fermentation and immersion treatments on Cocoa Bean Shell Powder, NFNI, NFI, FNI, and FI treatments have a significantly different effect on color, antioxidant activity, and organoleptic of cocoa bean shell powder. All treatment of CBS has a yellow-red color with significantly different on $\mathrm{L}^{*}$ values following the order FNI $>$ NFNI $>$ FI $>$ NFI and the $a^{*}$ and $b^{*}$ values following the order FNI $<$ FI $<$ NFNI $<$ NFI. NFNI has the highest antioxidant activity with IC50 values of 12.93 ppm and total phenolic $4.33 \mathrm{~g} / 100 \mathrm{~g}$. The highest organoleptic test scoring by panelists was treatment FI with successive values of 7.70 for texture (very strong), 7.97 for aroma (very strong), 7.57 for color (very strong) so that treatment FI was selected for triangular test was carried out with cocoa powder. The aroma and texture parameters have significantly different quality characteristics at the level of $1 \%$. Whereas the color parameters have significantly different quality characteristics at the $5 \%$ level and the overall appearance parameters have quality characteristics that are not significantly different.

\section{REFERENCES}

ADEBO, O. A. and GABRIELA MEDINA-MEZA, I. 2020. Impact of Fermentation on the Phenolic Compounds and Antioxidant Activity of Whole Cereal Grains: A Mini Review. Molecules, 25(4): 927. 
AFOAKWA, E. O., KONGOR, J. E., FELIX TAKRAMA, J., SIMPSON BUDU, A. and MENSAH-BROWN, H. 2013. Effects of Pulp Preconditioning on Total Polyphenols, O-diphenols and Anthocyanin Concentrations during Fermentation and Drying of Cocoa (Theobroma cacao) Beans. Journal of Food Science and Engineering, 3: 235-245.

AFOAKWA, E. O., PATERSON, A., FOWLER, M. and RYAN, A. 2008. Flavor formation and character in cocoa and chocolate: A critical review. Critical Reviews in Food Science and Nutrition, 48(9): 840-857.

AFOAKWA, E. O., QUAO, J., TAKRAMA, F. S., BUDU, A. S. and SAALIA, F. K. 2012. Changes in the Polyphenol in Fermented Beans. International Food Research Journal, 19(3): 1071-1077.

AIKPOKPODION, P. E. and DONGO, L. N. 2010. Effect of fermentation intensity on polyphenols and antioxidant capacity of cocoa beans. Int. J. Sustain. Crop Prod., 5(4): 66-70.

APRIYANTO, M., SUTARDI, SUPRIYANTO and HARMAYANI, E. 2016. Study on effect of fermentation to the quality parameter of cocoa bean in Indonesia. Asian Journal of Dairy and Food Research, 35(2): 160-163.

BARIŠIĆ, V., JOZINOVIĆ, A., FLANJAK, I., ŠUBARIĆ, D., BABIĆ, J., MILICEVIĆ, B., DOKO, K. and ACKAR, D. 2020. Difficulties with use of cocoa bean shell in food production and high voltage electrical discharge as a possible solution. Sustainability, 12(10): 3981.

CAMU, N., WINTER, T. D., ADDO, S. K., TAKRAMA, J. S., BERNAERT, H. and VUYST, L. D. 2008. Fermentation of cocoa beans: influence of microbial activities and polyphenol concentrations on the flavour of chocolate. Journal of the Science of Food and Agriculture, 88(13): 2288-2297.

DA SILVA MEDEIROS, N., KOSLOWSKY MARDER, R., FARIAS WOHLENBERG, M., FUNCHAL, C. and DANI, C. 2015. Total Phenolic Content and Antioxidant Activity of Different Types of Chocolate, Milk, Semisweet, Dark, and Soy, in Cerebral Cortex, Hippocampus, and Cerebellum of Wistar Rats. Biochemistry Research International, 2015: 294659.

DE BRITO, E. S., GARCÍA, N. H. P., GALLÃO, M. I., CORTELAZZO, A. L., FEVEREIRO, P. S. and BRAGA, M. R. 2001. Structural and chemical changes in cocoa (Theobroma cacao L.) during fermentation, drying and roasting. Journal of the Science of Food and Agriculture, 81(2): 281-288.

DI MATTIA, C., MARTUSCELLI, M., SACCHETTI, G., SCHEIRLINCK, I., BEHEYDT, B., MASTROCOLA, D. and PITTIA, P. 2013. Effect of Fermentation and Drying on Procyanidins, Antiradical Activity and Reducing Properties of Cocoa Beans. Food and Bioprocess Technology, 6(12): 3420-3432.

DIREKTORAT JENDERAL PERKEBUNAN. 2016. Statistik Perkebunan Indonesia, Jakarta. Sekretariat Direktorat Jenderal Perkebunan.

GU, F., TAN, L., WU, H., FANG, Y., XU, F., CHU, Z. and WANG, Q. 2013. Comparison of Cocoa Beans from China, Indonesia and Papua New Guinea. Foods, 2(2): 183-197.

HANDOJO, L., TRIHARYOGI, H. and INDARTO, A. 2019. Cocoa bean shell waste as potential raw material for dietary fiber powder. International Journal of Recycling of Organic Waste in Agriculture, 8(s1): 485-491.

HATMI, R. U. and RUSTIJARNO, S. 2012. Teknologi Pengolahan Biji Kakao Menuju Sni Biji Kakao 01-2323-2008. Perpustakaan Nasional, Katalog Dalam Terbitan (KDT). BPTP Yogyakarta.

HAYATI, R., YUSMANIZAR, MUSTAFRI and FAUZI, H. 2012. Kajian Fermentasi dan Suhu Pengeringan pada Mutu Kakao (Theobroma cacao L.). Jurnal Keteknikan Pertanian, 26(2): 129-135.

INDAH, H., PUTRI, F. and UTAMA, G. L. 2015. Preliminary studies of halophilic yeasts antimicrobial activities isolated from cocoa bean pulp towards E. coli and Salmonella spp. International Journal on Advanced Science, Engineering and Information Technology, 5(2): 107-109.

INDRIATI, G., SUSILAWATI and PUSPITASARI, M. 2020. Insect diversity of cacao (Theobroma cacao L.) plantation under different shade trees in Pakuwon, Sukabumi. IOP Conference Series: Earth and Environmental Science, 418: 012017.

KAYAPUTRI, I. L., SUMANTI, D. M., DJALI, M., INDIARTO, R. and DEWI, D. L. 2014. Kajian Fitokimia Ekstrak Kulit Biji Kakao (Theobroma Cacao L.). Chimica et Natura Acta, 2(1): 83-90.

LOBO, V., PATIL, A., PHATAK, A. and CHANDRA, N. 2010. Free radicals, antioxidants and functional foods: Impact on human health. Pharmacognosy Reviews, 4(8): 118-126.

MISNAWI and SELAMAT, J. 2003. Effect of Cocoa Bean Polyphenols on Sensory Properties and Their Changes During Fermentation. Pelita Perkebunan, 19(2): 90-103.

NDUKWU, M. C. and UDOFIA, M. 2016. Kinetics of change in colour and some bio-chemical composition during fermentation of cocoa bean Kinetics of change in colour and some bio-chemical composition during fermentation of cocoa bean. Cogent Food \& Agriculture, 48(1): 1268743.

PATHARE, P. B., OPARA, U. L. and AL-SAID, F. A.-J. 2013. Colour Measurement and Analysis in Fresh and Processed Foods: A Review. Food and Bioprocess Technology, 6(1): 36-60.

PEÑA-SALDARRIAGA, L. M., PÉREZ-ALVAREZ, J. A. and FERNÁNDEZ-LÓPEZ, J. 2020. Quality Properties of Chicken Emulsion-Type Sausages Formulated with Chicken Fatty Byproducts. Foods, 9(4): 507.

REDGWELL, R., TROVATO, V., MERINAT, S., CURTI, D., HEDIGER, S. and MANEZ, A. 2003. Dietary fibre in cocoa shell: Characterisation of component polysaccharides. Food Chemistry, 81(1): 103-112. 
ROHMAH, J., SAIDI, I. A., RINI, C. S., PURWANTO, Z. A. P., TIANA, K. H. and PUTRI, T. C. R. 2020. Antioxidant activity assay of white Turi (Sesbania grandiflora (L.) Pers.) extracts using DPPH radical scavenging method. Pharmaciana, 10(3): 257-268.

ROJO-POVEDA, O., BARBOSA-PEREIRA, L., ZEPPA, G. and STÉVIGNY, C. 2020. Cocoa Bean Shell—A ByProduct with Nutritional Properties and Biofunctional Potential. Nutrients, 12(4): 1123.

ROMANIELLO, R., LEONE, A. and PERI, G. 2015. Measurement of food colour in L*a*b* units from RGB digital image using least squares support vector machine regression. Journal of Agricultural Engineering, 46(4): 138.

SEPTIANTI, E., SALENGKE, LANGKONG, J., SUKENDAR, N. K. and HANIFA, A. P. 2020. Characteristic Quality of Pinrang's Cocoa Beans During Fermentation Used Styrofoam Containers. Canrea Journal: Food Technology, Nutritions, and Culinary Journal, 3(1): 10-25.

SERRA BONVEHÍ, J. and VENTURA COLL, F. 1997. Evaluation of bitterness and astringency of polyphenolic compounds in cocoa powder. Food Chemistry, 60(3): 365-370.

SHAHIDI, F. and AMBIGAIPALAN, P. 2015. Phenolics and polyphenolics in foods, beverages and spices: Antioxidant activity and health effects - A review. Journal of Functional Foods, 18: 820-897.

SMUDA, S. S., MOHSEN, S. M., OLSEN, K. and ALY, M. H. 2018. Bioactive compounds and antioxidant activities of some cereal milling by-products. Journal of Food Science and Technology, 55(3): 1134-1142.

SUAZO, Y., DAVIDOV-PARDO, G. and AROZARENA, I. 2014. Effect of Fermentation and Roasting on the Phenolic Concentration and Antioxidant Activity of Cocoa from Nicaragua. Journal of Food Quality, 37(1): 50-56.

SUDIBYO, A. 2017. Effect of Processing Techniques on Flavour and Characteristics of Cocoa Processed and Chocolate Products. Jurnal Industri Hasil Perkebunan, 12(1): 1-13.

TARANTO, F., PASQUALONE, A., MANGINI, G., TRIPODI, P., MIAZZI, M. M., PAVAN, S. and MONTEMURRO, C. 2017. Polyphenol Oxidases in Crops: Biochemical, Physiological and Genetic Aspects. Int. J. Mol. Sci., 18(377): 377.

TOMAS-BARBERÁN, F. A., CIENFUEGOS-JOVELLANOS, E., MARÍN, A., MUGUERZA, B., GIL-IZQUIERDO, A., CERDÁ, B., ZAFRILLA, P., MORILLAS, J., MULERO, J., IBARRA, A., PASAMAR, M. A., RAMÓN, D. and ESPÍN, J. C. 2007. A new process to develop a cocoa powder with higher flavonoid monomer content and enhanced bioavailability in healthy humans. Journal of Agricultural and Food Chemistry, 55(10): 3926-3935.

TOWAHA, J., ANGGRAINI, D. A. and RUBIYO. 2012. Keragaan Mutu Biji Kakao dan Produk Turunannya pada Berbagai Tingkat Fermentasi: Studi Kasus di Tabanan, Bali. Pelita Perkebunan, 28(3): 166-183.

UTAMA, G. L., IRENA, F., LEMBONG, E., KAYAPUTRI, I. L., TENSISKA, T. and BALIA, R. L. 2020. The Utilization of Vegetable and Fruit Wastes for Saccharomyces cerevisieae Cell Wall Based $\beta$-Glucan Production with Antioxidant Activity. Acta Universitatis Agriculturae et Silviculturae Mendelianae Brunensis, 68(1): 119-127.

UTAMI, R. R., SUPRIYANTO, S., RAHARDJO, S. and ARMUNANTO, R. 2017. Aktivitas Antioksidan Kulit Biji Kakao dari Hasil Penyangraian Biji Kakao Kering pada Derajat Ringan, Sedang dan Berat. Agritech, 37(1): 89.

VALVERDE GARCÍA, D., PÉREZ ESTEVE, É. and BARAT BAVIERA, J. M. 2020. Changes in cocoa properties induced by the alkalization process: A review. Comprehensive Reviews in Food Science and Food Safety, 19(4): 2200-2221.

WAHYUDI, T. R. P. T. and PUJIYANTO. 2013. Kakao, Manajemen Agribisnis Dari Hulu Hingga Hilir (Jakarta: Penebar Swadaya), Jakarta. Penebar Swadaya.

WAHYUNI, M. F., YUNITA, D., YUSRIANA, AISYAH, Y., LAHMER, R. A. and MUGAMPOZA, D. 2018. Chemical and Microbiological Characteristics of Cocoa Beans from Pidie District, Aceh Province, Indonesia. Proceeding of The $8^{\text {th }}$ AIC: Health and Life Sciences, 8(1): 113-121.

WIJAYA. M., M., WIHARTO, M. and ANWAR, M. 2018. Cellulose Compound of Cacao Waste and Chemical Composition of Cacao Vinegar with GC-MS Method. JKPK (Jurnal Kimia Dan Pendidikan Kimia), 2(3): 191.

Contact information

Gemilang Lara Utama: g.l.utama@unpad.ac.id (corresponding author)

Elazmanawati Lembong: elazmanawati.lembong@unpad.ac.id 
